\title{
Teacher Induction Pathway of Physical and Health Education: A Case Study
}

\author{
Marie-Claude Rivard ${ }^{1}$, Johanne Grenier ${ }^{2}$, Mylène Leroux ${ }^{3}$, Sylvain Turcotte $^{4}$, Linda Morency ${ }^{5} \&$ Claude \\ Bordeleau $^{5}$ \\ ${ }^{1}$ Département des sciences de l'activité physique, Université du Québec à Trois-Rivières, Trois-Rivières, Canada \\ ${ }^{2}$ Département des sciences de l'activité physique, Université du Québec à Montréal, Montréal, Canada \\ ${ }^{3}$ Department des sciences de l'éducation, Université du Québec en Outaouais, Gatineau, Canada \\ ${ }^{4}$ Départment des sciences de l'activité physique, Université de Sherbrooke, Sherbrooke, Canada \\ ${ }^{5}$ Département des sciences de l'éducation, Université du Québec à Chicoutimi, Chicoutimi, Canada \\ Corresponding author: Marie-Claude Rivard, Département des sciences de l'activité physique, Université du \\ Québec à Trois-Rivières, Trois-Rivières, QC., G9A5H7, Canada. E-mail: marie-claude.rivard@uqtr.ca
}

Received: February 6, 2020 Accepted: March 21, 2020 Online Published: March 23, 2020

doi:10.5539/jel.v9n3p1 URL: https://doi.org/10.5539/jel.v9n3p1

\begin{abstract}
This article aims to describe teacher induction (TI) with reference to two physical and health education (PHE) teachers based on three variables: 1) self-efficacy, 2) motivation and 3) satisfaction. Our case study relies on individual telephone interviews conducted during each teacher's first five years of teaching and allows for describing the perceptions of these two teachers who persevered in the profession. The findings reveal that self-efficacy relates above all to harmonious relations with students and teaching colleagues, an experienced teacher in particular, and evolves over the course of TI through a process of introspection undertaken by the new teacher. A surprising observation is that, despite the difficult conditions of substitute teaching during TI, teachers maintain that it offers diverse contexts and opportunities for learning about the profession; thus, substitute teaching appears to positively impact self-efficacy. The relatively high motivation fluctuates over time, based on whether it is approached positively in terms of professional relations, or negatively in terms of job insecurity. The same holds true for satisfaction, which alters over the years, either upwards if based on positive contact with students or downwards if based on difficult hiring conditions. During the induction process, satisfaction evolves towards the quest for academic freedom and an awareness of the teacher's impact on his or her students. The conclusion explains how a strong feeling of self-efficacy can contribute to perseverance in the profession during the TI phase, even in the presence of difficult job conditions.
\end{abstract}

Keywords: teacher induction, retention, self-efficacy, motivation, satisfaction, teachers' perceptions, physical and health education

\section{Literature Review}

Teacher induction (TI) is an ambiguous and polysemous concept that refers to a dynamic transition of integration (Jeffrey \& Sun, 2008) and adaptation (Martineau, Gervais, Portelance, \& Mukamurera, 2008) to the teaching profession, generally during the first five years of practice. The passage from intern to teacher confronts teachers with certain realities not experienced during internship (Mukamurera, 2018; Pillen, Beijaard, \& den Brok, 2013). The teacher generally starts work in conditions of insecurity (Aubin, 2017; Portelance, Mukamurera, Martineau, \& Gervais, 2008) and takes on the heaviest and most complex tasks (CSE, 2004; Mukamurera, 2018). She/He is often sent to difficult institutions (Borman \& Dowling, 2008) with inadequate resources (OCDE, 2014). Lack of experience and confidence is a real problem (Mukamurera, Bourque, \& Ntebutse, 2010) for new teachers are expected to assume the same responsibilities as those with practice (Karsenti, Collin, \& Dumouchel, 2013; Le Maistre \& Paré, 2010). The new teacher's idealized image of the profession (Hammerness, 2008; Hudson, 2009) is then shattered by "reality shock" (Stroot, 2003). S/he must therefore cross a difficult but crucial passage (Tait, 2008) from survival to mastery of professional competencies (Mukamurera, 2018).

These few observations explain the higher attrition rate noted during the TI stage (De Stercke, 2014; Karsenti et al., 2013). Although single careers are increasingly rare in the era of globalization and national and international 
mobility (Johnson \& Birkeland, 2003; OCDE, 2005), these early departures from the teaching profession, whether volontary or not, command attention (Karsenti et al., 2013). A number of international studies reveal a $20 \%$ to $50 \%$ attrition rate for early career teachers (OCDE, 2005; Sharplin, O'Neill, \& Chapman, 2011). In Canada, this is estimated at 30\% (Canadian Teachers' Federation, 2004).

There are few studies in the literature on the experience of teachers who persevere during the induction process (Whipp \& Salin, 2018). In this context, an improved understanding of these teachers' pathway may contribute to the development and implementation of strategies aimed at reducing the attrition rate (Karsenti et al., 2013).

\subsection{Teacher Induction in Quebec}

Education is a provincial responsibility. Thus, in Quebec, a teacher who completes a four-year teacher training degree can apply to one of 72 school boards in accordance with the particular rules established in collaboration with the teachers' unions. Generally, the first jobs progress from substitute teaching to a contract to a regular position, at both the primary (6-11 years) and secondary (12-17) levels. Different systems are implemented to recruit an applicant who is usually called early in the day to replace a teacher. Such substitute teaching jobs occur in diverse contexts: primary and secondary schools, multiple schools, classes of special needs students, various socioeconomic environments and the teaching of different subjects. Contracts are distributed in function of a list of priorities based on the experience accumulated within a same school board. These contracts, sometimes completed with substitute teaching, vary from a few weeks to a school year and involve a percentage of teaching tasks. Often, one may obtain a PHE contract completed with another subject and divided among two, three or even four schools. A permanent position is awarded when a teaching vacancy opens up or a new position is created within a school board.

\subsection{Key Teacher Induction Challenges in Physical and Health Education}

TI challenges in PHE include important characteristics that justify studying "specific teacher" stories (Stroot \& Ko, 2006), since the structure of the teaching task is unique. Among other things, the time available for teaching is reduced by the transition to the coatroom and the installation of specialized materials (Demirhan, Bulca, Saçl, \& Kangalgil, 2014). The task is heavier owing to the number of students per class, a teaching task divided among several schools and the teacher's involvement in extracurricular activities (Aubin, 2017; Cruz \& $\mathrm{Li}$, 2009), not to mention the isolation of PHE teachers (Leroux, Beaudoin, Grenier, Turcotte, \& Rivard, 2016). The physical environment, which plays a key role during the TI of PHE teachers, may present problems including outdated or lack of sports equipment, a space that's too small or poorly adapted to groups of students (Demirhan et al., 2014) and a work area physically isolated from the school's other teaching areas (Aubin, 2017; Parker, Patton, \& Tannehill, 2012; Richards, 2015). As well, the PHE teacher becomes aware that the subject is marginalized (Henninger, 2007) and viewed as less important by both the administrators (Aubin, 2017; Demirhan et al., 2014) and the students (Eldar, Nable, Schechter, \& Marzin, 2003).

The new PHE teacher must follow the induction program within this context. Since TI can be studied from multiple angles, Mukamurera (2018) proposes five dimensions, of which one is the personal and psychological dimension referring "... to the affective and emotional aspects of integration, and to personal growth" (p. 198). Said dimension comprises key factors including self-efficacy, motivation and satisfaction, the three variables of interest in this study.

\subsection{Self-Efficacy}

In the present case study, the self-efficacy, according to Bandura (2007), corresponds to teachers' confidence in their capacity to achieve goals in their field of activity: PHE. Future teachers' self-efficacy increases significantly during initial training, then drops in the first year of TI (Hoy \& Spero, 2005), probably owing to previous experiences, training and the characteristics of the new teacher's host environment (Hebert \& Worthy, 2001). Dagenais-Desmarais et al. (2014) indicate that administrators' assignment of tasks tailored to teachers' strengths together with the confidence shown by colleagues concerning their capacity to accomplish these tasks contribute to the development of new teachers' self-efficacy. Mäkelä and Whipp (2015) believe that PHE teachers with a strong self-efficacy are more likely to persevere in the profession.

\subsection{Motivation}

Self-determined motivation (Deci \& Ryan, 2000) appears linked to an improved rate of engagement and stronger perseverance among teachers (Perry, Brenner, Collie, \& Hofer, 2015). Thus, satisfaction of the needs for autonomy, competence and relatedness impacts motivation at work, engagement and satisfaction (Gagné \& Deci, 2005). According to Abós et al. (2019), experienced PHE teachers are more likely to become actively engaged in their teaching role and to experience greater satisfaction when their motivation is self-determined. There is little 
research on teachers' motivation during the TI stage, although motivation is frequently mentioned as a contributing factor in their perseverance (Abós et al., 2019; Desmeules, Hamel, \& Frenette, 2017).

\subsection{Satisfaction}

Satisfaction in the workplace, defined by Weiss (2002) as an attitude based on an individual's evaluation of his or her work, includes overall satisfaction at work or in function of certain aspects of work such as salary, working conditions and interpersonal relations with colleagues or students (Skaalvik \& Skaalvik, 2011). Satisfaction relates to work skills (Mäkelä \& Hirvensalo, 2015; Ünlü \& Filiz, 2019) and appears to impact teacher retention (Hung, 2012). Furthermore, teachers who experience greater satisfaction appear to make the best teachers (Hung, 2012), and their students learn better (McCluney, Fallaize, \& Schempp, 2018) and are more motivated (Ünlü \& Filiz, 2019). Experienced PHE teachers' value job security, a task that allows for physical activity, a postive work climate and contact with students (Bizet, Laurencelle, Lemoyne, Larouche, \& Trudeau, 2010). Their level of satisfaction varies from medium to high (Richards, Washburn, \& Hemphill, 2017).

\subsection{Objective and Relevance}

TI in PHE evolves within a particular context, and an understanding of the induction pathway of teachers who continue in the profession would shed new light on the reasons for perseverance. Accordingly, this article aims to describe the first five years of TI with reference to two PHE teachers in terms of self-efficacy, motivation and satisfaction. Our study is unique in that it is rooted in a qualitative longitudinal research conducted over five years.

\section{Method}

\subsection{Research Design}

The research objective called for an in-depth study spread over time to determine the teachers' TI pathway. A qualitative approach based on a case study (Schwandt \& Gates, 2018) was privileged to obtain a rich description and complete interpretation of their lived experiences. The case study authorizes readers to determine the study's explanatory power within its own context (Borko, Liston, \& Whitcomb, 2007).

Within the frame of a broader research, participating early career PHE teachers, whose number varied with the years, were invited to discuss their TI at the start of each school year. They reviewed their pathway at the end of five years. The research obtained ethical approval, and the participants consented to participate during each interview.

\subsection{Sample}

Among those taking part in the broad research, two were selected because they had persevered in TI contexts common in Quebec: a work environment with some degree of job insecurity, late postings, residual tasks, work outside their field of competence and difficult environments, as described by Mukamurera and Fontaine (2017).

\subsection{Tool and Analysis Strategies}

Individual telephone interviews allowed us to obtain a thorough understanding of participants' experience (Yin, 2014). At each annual interview, the two teachers rated three questions regarding self-efficacy, motivation and satisfaction on a scale of 1 (min.) to 10 (max.). They then justified and explained each of the ratings based on three open questions. In addition, they mentioned their career outlook at the end of each year. The 10 interviews lasted about 45 minutes each and were recorded and fully transcribed in order to conduct a content analysis (Roulston, 2014) based on each of the three variables under study.

\section{Findings}

The results are presented separately for each teacher, Anna and Victor (pseudonyms are used). After describing their teaching context, they discussed their TI pathway in terms of self-efficacy, motivation and satisfaction. Finally, the presentation of their career perspectives at the end of each year showed that context, self-efficacy, motivation and satisfaction had a major impact on their professional objectives. They took stock of the previous year in their comments and revealed their expectations for the following year.

\subsection{Anna}

\subsubsection{Variable Teaching Contexts}

Anna, 23 years old at the beginning of the study, obtains during the first year a 12 -week contract $(64 \%)$ (The \% associated with the task represents the fraction of a full-time task. For example, a contract of $20 \%$ means the teacher will teach 1 day a week and always to the same groups of students for the duration of the contract.) divided among two primary schools, which she completes with substitute teaching. When the contract ends, 
some 25 schools contact her for substitute teaching in various contexts. During her second year of teaching, she lands a full-year PHE contract (42\%) divided among two primary schools, which she again completes with substitute teaching in PHE. She appreciates this contract: "I learn a lot thanks to the teachers who work with me [...]. I have my own students for the whole year." In year three, Anna shares her task between a primary school PHE contract (68\%) in two schools, and substitute teaching. The contract has certain disadvantages all the same: "It's difficult. In one school, I work only mornings, so I'm not around for meetings and committees." In the fourth year, Anna gets a primary school contract (70\%). She appreciates the chance to focus on work in a single school, where she sometimes completes her task by replacing her PHE colleague. At the end of the fifth year, she was given a primary school contract $(70 \%)$ divided among two schools for the full school year. After working two weeks, she leaves the school for the rest of the year to benefit from Quebec's Safe Maternity Leave Program owing to pregnancy.

\subsubsection{Self-Efficacy}

Anna rates herself $9 / 10$ for the first year (Figure 1). She explains: "When my contract ended, the students were happy with the work I did. And the teachers congratulated me for my professionalism." After the second school year, she maintains a rate of 9 , indicating she's making constant progress and wants to keep up her performance. In year three $(9 / 10)$ she must then pass an interview to access contracts in the coming years and therefore sees the importance of developing her competencies to demonstrate the quality of her work. During the last two years $(9 / 10$ and $8 / 10)$, Anna feels it's very important to consolidate her competencies, but rates herself 8 in year five because the work context stands in the way of progress. To give one example example, she's unable to use certain technologies because the necessary materials are not available in her school.

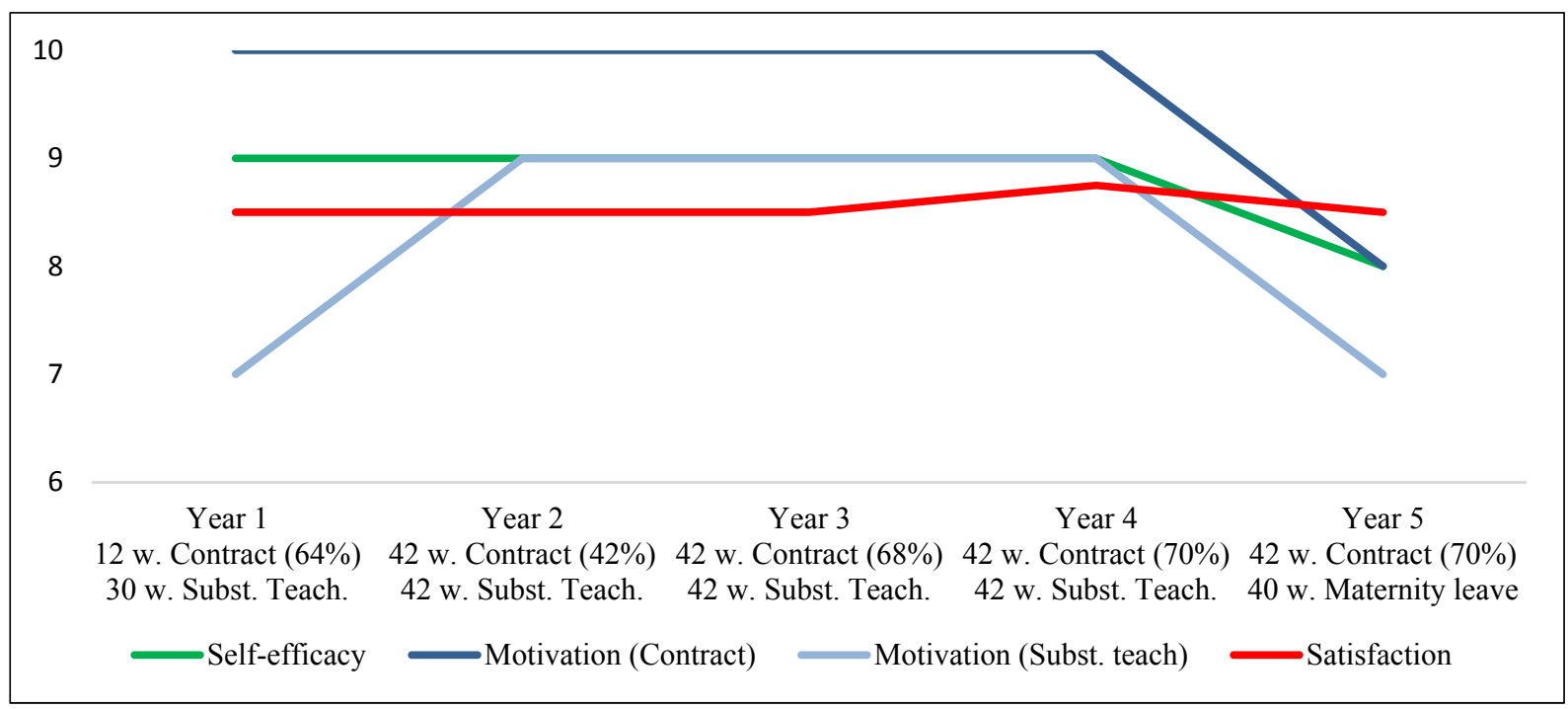

Figure 1. Teacher induction pathway: Anna

\subsubsection{Motivation}

Anna wishes to emphasize that her motivation during contract teaching is higher than what she experiences when substitute teaching. During the first year contract (10/10), she indicates: "The students are what motivate me; I develop a strong relationship with them right away. I enjoy seeing them again the next day, monitoring them, observing their progress." A relationship like this isn't possible in substitute teaching (7/10): "I don't know the students; in substitute teaching, I can't develop relationships." In year two, Anna continues to be motivated by the relationships she builds with students thanks to the contract (10/10). However, substitute teaching appears to motivate her further and she increases her motivation rate (9/10), "Since I often return to the same schools, the students recognize me. I enjoy seeing them again." She indicates that substitute teaching introduces her to other ways of functioning. During the third year, Anna cites the following reasons for her motivation during contract work (10/10): "working as a team, discovering new ways of seeing things, new activities, collaboration, improving day after day with my colleagues." She continues to be motivated by her students while substitute teaching $(9 / 10)$. In her fourth year, Anna gives two reasons for her motivation: she sees students she already knows during substitute teaching and collaborates with colleagues in the school where she has a contract. At the 
end of the fifth year, the year of maternity leave, she demonstrates concern about future contracts: "I noted 8 because I haven't started a work-life balance yet. That's stressful for sure." Another reason for this concern is her motivation during substitute teaching (7/10): "I find it's hard to leave at the last minute, after a call in the morning, it's a source of stress. I'm worried about substitute teaching when I go back to work."

\subsubsection{Satisfaction}

Anna rates her satisfaction at 8.5 for all five years of her TI. In year one, despite a few concerns, she indicates that the positive comments of students and colleagues contributed to her satisfaction. During the second year, in teaching contexts considered difficult, Anna recognizes that cooperation among colleagues influenced her satisfaction. In year three, she mentions that: "This year, I have the chance to work as part of a team with wonderful people, and I have students who are motivated to learn." In year four, Anna rates herself $8.5+$ because she works in a single school where she greatly appreciates her colleagues. Finally, in year five, her level of satisfaction remains stable: "I still like my work even though I'm not employed at the moment."

\subsubsection{Career Perspectives}

Anna's comments reveal the strong impact that teaching contexts and the three variables discussed in this article have on career perspectives. First, she says (Year 1) she wants to teach PHE at the primary or secondary level and has no interest in administrative tasks. Next (Year 2), she notes she prefers the primary level but will accept the most important contract. During the last three years, she confirms that opportunities will determine her choice of teaching level, primary or secondary. In her final interview (Year 5), she adds she wants to move on to another stage: "I'm in a hurry to have stability, to be able to monitor my students, to return to the same school every year. I want to know what it's like not to have to get used to a new school all the time, to keep introducing myself to the students."

\subsection{Victor}

\subsubsection{Variable Teaching Contexts}

Victor, 25 years old at the start of the study, completed his training differently because he was required, for academic reasons, to do an eight-week internship after four years of training. Thus, in year one, he starts his career by substitute teaching at the secondary level (10 weeks) while waiting to complete the missing internship, which has been scheduled for fixed dates (November and December). Next, he enjoys an internship at a primary school (8 weeks): "It's a dynamic, interesting environment, with small groups in a large gymnasium. Working with the students was easy." He then returns to substitute teaching ( 7 weeks), which he enjoys less: "I don't like substitute teaching in secondary school. I get along well with some of the students, but with certain groups I have problems." He ends the school year with a primary school contract (90\%). Victor begins year two with 13 weeks of substitute teaching and follows it with a primary school contract $(85 \%)$ obtained because of a change in situation: "In the end, I didn't replace that teacher in secondary [...] his surgery was postponed." In year three, he does some substituting, then obtains a primary school contract $(20 \%)$ and completes it with substitute teaching. In year four, he again lands a primary school contract $(50 \%)$ and completes it once more with subsitute teaching. At the end of the school year, he neglects to carry out an administrative procedure, which prevents him from accessing secondary school contracts available for the following year. As a result, his fifth year is divided into four periods: 1) substitute teaching (10 weeks), 2) a 12-week PHE contract at the secondary level, 3) substitute teaching (10 weeks), and 4) a primary school contract (100\%) for the final 10 weeks.

\subsubsection{Self-Efficacy}

Victor rates his self-efficacy between 8 and 9 depending on the years (Figure 2). In year one, he rates himself a 9: "I'd say I'm competent; if they offer me a class in a school, I'll be able to do a pretty good job." In his second year, he rates himself an 8 . These comments suggest he may have overestimated himself in year one. As regards the 8.5 rating in year three, Victor notes: "I look for new information, new tools all the time. I question myself often. I work with a teacher who has a lot of experience; I can share with him." In year four, Victor still rates himself an 8.5. Then, after five years of teaching, he explains his 9 rating as follows: "I've seen a lot of different situations. I'm improving because I always review the work I do. Co-teaching helps me a lot. I see another way of doing things; I listen to some good ideas and adapt them to my own situation." 


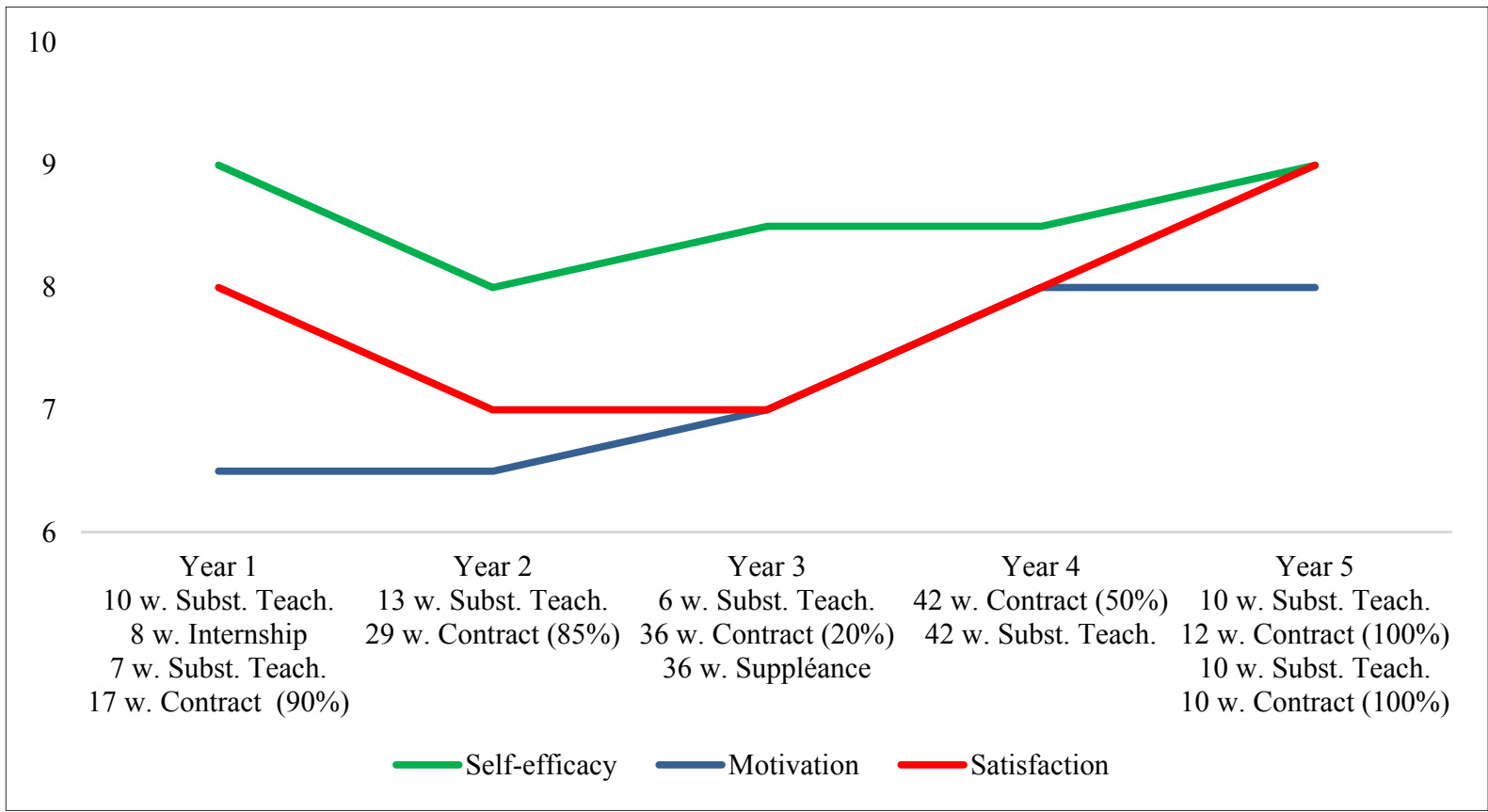

Figure 2. Teacher induction pathway: Victor

\subsubsection{Motivation}

In the first year, Victor rates himself a 6.5: "What motivates me is the joy of teaching, of transmitting knowledge to young people, of building relationships with them. But what demotivates me is that I don't know exactly how to go about getting a job, how it's all going to work out, whether I'm going to have a contract, how long it will take to get a job." In year two (6.5/10), he recalls the difficulties of job insecurity. In the third year, his motivation is a bit higher (7/10), notably because of the hope of a bigger contract the following year, but he shows concern about a contract divided among several schools: "It's hard to find my right place when I'm moving from school to school." Victor rates himself an 8 for the last two years. He explains his fourth year by the "friendly teaching environment" in which he evolves. Then, at the end of the project, he notes: "The end-of-year contract gave me a boost. At the start of the year, I was thinking about changing jobs. I'm tired of starting every year with crumbs [tiny portions of tasks], of doing substitute teaching everywhere. But I decided to be patient, because this is what I like to do."

\subsubsection{Satisfaction}

In year one, Victor rates his satisfaction at 8 during his internship: "I had many good comments from the students, they thanked me for my teaching and said they learned a lot. I know I wasn't an entertainer." During his second year, he lowers his rate to 7. He's happy to have a contract but misses the congenial atmosphere of the primary school where he interned: "I' $d$ have liked to continue in the primary school where I was last year. I'm happy with my contract, but I'd prefer to start the year with the classes to get to know them better. I feel kind of limited by the planning of the teacher I'm replacing. I'd have liked to teach content I'm more comfortable with." In year three, his satisfaction rate is still 7 because, among other reasons, he finds substitute teaching boring. In the fourth year, a number of factors including the prospect of advancing in order of priority, his present contract (50\%), co-teaching with a much-valued colleague and his school's work team all help raise his rate of satisfaction to 8 . Then, after five years, his satisfaction rate of 9 is the result of self-efficacy: "I have more experience; I feel more comfortable with my subject and with classroom management. During substitute teaching, I worked with students 5 to 16 years old in different environments, and I gained different kinds of experience."

\subsubsection{Career Perspectives}

Victor's comments on his career outlook highlight the significant impact of teaching contexts and motivation on his professional future. In the beginning, his objective is clear: to teach physical education. However, he wavers throughout his TI pathway between leaving teaching for a stable job and continuing to teach. After five years, he recalls he would like to teach in a single school to build something with the students, develop projects, become 
integrated into the school and become a pillar, as he really loves the profession. He also expresses a certain irritation: "It's frustrating, I finished my training, I'm motivated, I want to give my time, I'm ready to do everything, but I'm blocked by a system that stops me from doing what I want. But, I try to be positive. I'm the last one on the list of postings. Each year, I never know what's going to happen."

\section{Discussion}

Recall that our research objective is to describe the TI pathway of two PHE teachers on the basis of self-efficacy, motivation and satisfaction.

\subsection{Self-Efficacy}

Findings indicate that Anna and Victor's self-efficacy is relatively high and stable, and certain observations can be made from an examination of their pathway. At the start of TI, there is consensus regarding the self-efficacy fostered by harmonious relations with both students and colleagues. Dagenais-Desmarais et al. (2014), moreover, stress that the confidence shown to new teachers regarding their capacity to accomplish educational tasks contributes to the development of self-efficacy. Although the nature of the professional relations between new and experienced teachers has not been examined (e.g., co-teaching, mentoring), it may be consistent with the thinking of Blankenship and Coleman (2009), who stress that co-teaching with a colleague having similar values is an advantage for perseverance in teaching PHE. Morris, Usher and Chen (2017) go one better by viewing co-teaching as a form of modeling for early career teachers. Whatever the case, the assistance of an experienced teacher impacted these new teachers' sense of self-efficacy, and said modeling may be the reason for this.

The future teachers' self-efficacy tends to diminish during the first year of TI (Hoy \& Spero, 2005), or even during the first two years (Mukamurera, 2018). This trend was observed for Victor. Was this self-efficacy overestimated at the start, then adjusted more accurately in the field, as he suggested? It may be relevant to examine this question using a larger sample.

During TI, Anna and Victor's self-efficacy is adjusted thanks to their gradual introspection and the difficult conditions of substitute teaching, which they view positively nonetheless. These difficult conditions in fact offer a broad range of experiences including diverse contexts and disciplines, which, in turn, help them become better at their job. This last observation offers a new perspective on the difficult work conditions during TI, which generally discourage the development of self-efficacy (Mukamurera, 2018).

\subsection{Motivation}

It appears that type of employment is the main reason for fluctuating motivation levels during the first five years of professional integration. A source of motivation, the contract is considered to offer the stability required to develop relationships with students and evaluate their progress in the opinion of Abós et al. (2019). Over the years, contact with the same students and collaboration with colleagues have nuanced the comments of Anna and Victor. Consistent with Marquis (2017), sources of motivation include, for the most part, relations with teaching colleagues versus all other school staff members. Drion (2017) agrees by indicating that relationship with colleagues influences the motivation to persist or not in the teaching profession. A source of demotivation, substitute teaching is perceived as an unstable situation marked by professional uncertainty, even the desire to leave the profession as in Victor's case. Along with the accompanying job insecurity, it is characterized by a long road towards possible permanent employment that makes it difficult to plan for the future. Studies by Drion (2017) establish a parallel between job insecurity in teaching and the harsh reality of starting over again at the beginning of each school year.

At the completion of the analysis, work-life balance is also discussed as a potential source of motivation. A longitudinal study subsequent to the integration process would be required to highlight concerns relating to the parental role, here a personal objective alongside professional objectives. It's too early for a conclusion, certainly, but the literature does in fact establish relations between various actors, such as the family, who are likely to influence a teacher's motivation (Marquis, 2017). According to Théorêt and Leroux (2014), the support of the entourage and the family constitutes an environmental protective factor for teachers in general.

Finally, the reasons explaining Anna and Victor's motivation, although to all appearances external (contract, stable employment), are linked to the relations they develop with students and colleagues. The desire to build bonds with the students, to have them progress and monitor their progress, is an internal motivation above all. This observation accords with that of Van den Berghe et al. (2013), who show that internal sources of motivation may constitute a "buffer" against the development of emotional exhaustion. Although at this stage it's too soon to form an opinion regarding Anna and Victor's risks of exhaustion, it's interesting to note that their comments make no mention of the burnout (Fives, Hamman, \& Olivarez, 2007) and psychological stress (Mukamurera et 
al., 2010) documented in the literature. This seems to be in line with stable or even higher satisfaction rates over the years for both teachers.

\subsection{Satisfaction}

Findings indicate that the moderately high satisfaction of both participants is influenced first and foremost by good relationships with the students. The literature on PHE shows mixed results regarding whether teachers' level of satisfaction at work is moderate (Karacan-Doğan, Akyel, \& Doğan, 2018) or high (Gürbüz, 2008) as in the present study, notably in terms of the social relationships developed in the workplace (Nascimento, Folle, Rosa, \& Both, 2016). In this respect, a previous study indicates that the key factors determining teachers' satisfaction are their social environment and relationships with various reference groups (Skaalvik \& Skaalvik, 2011). A further study shows that teachers of so-called "practical" subjects like physical education or arts and crafts, are more satisfied with their work than those teaching so-called "theoretical" subjects like mathematics or history (Van Maele \& Van Houtte, 2012).

Apart from good relationships with students and a stable employment contract, the TI pathway makes it possible to trace a certain evolution in the factors contributing to Anna and Victor's satisfaction. Teachers' collaboration and mutual aid become positive elements regarding satisfaction, which agrees with a conclusion by Whipp and Salin (2018) to the effect that a positive work climate influences teachers' decision to continue teaching PHE. Autonomy, confidence with subject matter and a growing awareness of the teacher's impact on students are an added value to satisfaction and at the same time echo the work skills highlighted in the literature (Mäkelä \& Hirvensalo, 2015; Ünlü \& Filiz, 2019). According to McCluney et al. (2018), students of teachers with higher satisfaction levels learn better. This is of interest here insofar as the students' motivation to learn appears, in turn, to influence level of satisfaction, particularly with respect to Anna. A question arises: Does teacher satisfaction impact students' learning, or do motivated students impact teacher satisfaction? To our knowledge, this issue is not discussed in the literature and merits particular attention for future research.

\section{Conclusion}

The present study does not allow for generalizing results. An exploration of perceptions using a combination of validated tools and interviews would no doubt have reinforced data accuracy. Furthermore, the study's strength lies in its longitudinal perspective, which has the advantage of offering a more thorough understanding of the issue examined, that is, the TI pathway of two teachers who are persevering in the teaching of PHE.

In the early stages of teaching, self-efficacy is displayed above all through harmonious relationships with students and colleagues and with an experienced teacher in particular; during the TI process, it is displayed through a process of introspection undertaken by the new teacher. A surprising fact observed during TI relates to the difficult conditions of substitute teaching, which appear to positively impact self-efficacy by offering diverse contexts and learning opportunities that are beneficial to the new teacher. We note a relatively high motivation over time in favor of the contract, instead of substitute teaching, for its stability which first relationships with the same students and then collaboration with colleagues. Conversely, lower motivation relates to substitute teaching perceived as instability that generates professional uncertainty. The same holds true for satisfaction, which alters over the years. At the start of TI, satisfaction increases when based on positive contact with students and teacher collaboration, and decreases when based on difficult hiring conditions. Then, during the induction process, satisfaction evolves towards a quest for academic freedom and a growing awareness of the teacher's impact on the students. One can reasonably assume that the two teachers in our study developed a kind of professional maturity during TI, one demonstrated by a self-distancing with respect to the students or a more detached and nuanced view of the profession.

This understanding of the pathway of two teachers who continue in their profession despite difficult contexts, paves the way for strategies that encourage perseverance. It appears that a key aspect of professional perseverance is, among other things, teachers' perception of difficult conditions. Indeed, the ability to discover opportunities for learning and professional development in the difficult conditions of substitute teaching is an undeniable asset for fostering self-efficacy. Furthermore, reducing substitute teaching to a minimum of schools while waiting long periods of time for contracts may help maintain motivation thanks to more frequent contact with the same students. The relationships formed with teaching colleagues, whether during substitute teaching or short contracts, may also contribute to satisfaction and, possibly, the decision to persevere. In the end, 'staying the course' in terms of one's career prospects while agreeing to adjust them to the opportunities offered looks to be an asset for new teachers' perseverance. Nevertheless, our findings invite the Ministry of Education to act to encourage the retention of our new teachers, combat their dropout, so that teachers in Quebec will enjoy the recognition they deserve. We believe this can be best achieved through improved hiring conditions. 


\section{References}

Abós, Á., Haerens, L., Sevil-Serrano, J., Morbée, S., Julián, J. A., \& García-González, L. (2019). Does the level of motivation of physical education teachers matter in terms of job satisfaction and emotional exhaustion? A person-centered examination based on self-determination theory. International Journal of Environmental Research and Public Health, 16(16), 2-15. https://doi.org/10.3390/ijerph16162839

Aubin, A. S. (2017). L'insertion professionnelle des enseignants en éducation physique et à la santé au primaire et au secondaire au Québec (Mémoire de maîtrise inédit). Université de Montréal, Canada. Retrieved from https://papyrus.bib.umontreal.ca/xmlui/handle/1866/19469

Bandura, A. (2007). Auto-efficacité, le sentiment d'efficacité personnelle. Bruxelles, Belgique: De Boeck.

Bizet, I., Laurencelle, L., Lemoyne, J., Larouche, R., \& Trudeau, F. (2010). Career Changes Among Physical Educators. Research Quarterly for Exercise and Sport, 81(2), 224-232. https://doi.10.1080/02701367.2010.10599669

Blankenship, T. B., \& Coleman, M. (2009). An examination of "wash-out" and workplace conditions of beginning physical education teachers. Physical Educator, 25(2), 97-111.

Borko, H., Liston, D., \& Whitcomb, J. (2007). Genres of empirical research in teacher education. [Editorial]. Journal of Teacher Education, 58(1), 3-11. https://doi.org/10.1177/0022487106296220

Borman, G. D., \& Dowling, N. M. (2008). Teacher attrition and retention: A meta-analytic and narrative review of the research. Review of Educational Research, 78, 367-409. https://doi.org/10.3102/0034654308321455

Conseil supérieur de l'éducation (CSE). (2004). Un souffle nouveau pour la profession enseignante: avis au ministre de l'Éducation. Québec, QC: Bibliothèque nationale du Québec.

Cruz, A., \& Li, C. (2009). The practice of the beginning secondary school physical education teachers. Asian Journal of Physical Education \& Recreation, 15(1), 61-81.

Dagenais-Desmarais, V., Forest, J., Girouard, S., \& Crevier-Braud, L. (2014). The importance of needsupportive relationships for motivation and psychological health at work. In N. Weinstein (Ed.), Human motivation and interpersonal relationships - Theory, research, and applications (pp. 263-297). Dordrecht: Springer, Netherlands. https://doi.org/10.1007/978-94-017-8542-6_12

De Stercke, J. (2014). Persévérance et abandon des enseignants débutants: La relève issue des Hautes Écoles (Thèse de doctorat inédite). Université de Mons-Hainaut, Belgique. Retrieved from https://tel.archives-ouvertes.fr/tel-00999263/document

Deci, E. L., \& Ryan, R. M. (2000). The "what" and "why" of goal pursuits: Human needs and the self-determination of behavior. Psychological Inquiry, 11(4), 227-268. https://doi.org/10.1207/S15327965PLI1104_01

Demirhan, G., Bulca, Y., Saçl1, F., \& Kangalgil, M. (2014). Physical education teachers' problems in practice and suggested solutions. Hacettepe University Journal of Education, 29(2), 57-68.

Desmeules, A., Hamel, C., \& Frenette, É. (2017). Programmes d'insertion professionnelle dans les commissions scolaires de Québec et persévérance des enseignants du primaire et du secondaire en début de carrière. Canadian Journal of Education, 40(2), 1-26.

Drion, C. (2017). Quel est le rôle du parcours d'insertion professionnelle des enseignants novices dans leur identité professionnelle au terme de leur première année d'enseignement? Thèse de doctorat inédite. Université catholique de Louvain, Belgique. Retrieved from http:// hdl.handle.net/2078.1/thesis:13083

Eldar, E., Nable, N., Schechter, C. T., \& Marzin, K. (2003). Anatomy of success and failure: The story of three novice teachers. Educational Research, 1, 29-48. https://doi.org/10.1080/0013188032000086109

Fédération canadienne des enseignantes et enseignants. (2004). Recrutement et maintien du personnel enseignant: Pourquoi les enseignants et enseignantes entrent dans la profession, y restent ou la quittent. Bulletin des Services Economiques et Services aux Membres, 5, 1-20.

Fives, H., Hamman, D., \& Olivarez, A. (2007). Does burnout begin with student-teaching? Analyzing efficacy, burnout, and support during the student-teaching semester. Teaching and Teacher Education, 23, 916-934. https://doi.org/10.1016/j.tate.2006.03.013

Gagné, M., \& Deci, E. L. (2005). Self-determination theory and work motivation. Journal of Organizational Behavior, 26, 331-362. https://doi.org/10.1002/job.322 
Gaikhorst, L., Beishuizen, J. J., Korstjens, I. M., \& Volman, M. L. (2014). Induction of beginning teachers in urban environments: An exploration of the support structure and culture for beginning teachers at primary schools needed to improve retention of primary school teachers. Teaching and Teacher Education, 42, 23-33. https://doi.org/10.1016/j.tate.2014.04.006

Gürbüz, Z. (2008). Examining the satisfaction with profession levels and professional burnout levels of the pre-school teachers working in Kars. Unpublished graduate dissertation. Marmara University Education/Sciences Institute, İstanbul.

Hammerness, K. (2008). "If you don't know where you are going, any path will do": The role of teachers' visions in teachers' career paths. The New Educator, 4(1), 1-22. https://doi.org/10.1080/15476880701829184

Hebert, E., \& Worthy, T. (2001). Does the first year of teaching have to be a bad one? A case study of success. Teaching and Teacher Education, 17, 897-911. https://doi.org/10.1016/S0742-051X(01)00039-7

Henninger, M. L. (2007). Lifers and troupers: Urban physical education teachers who stay. Journal of Teaching in Physical Education, 26, 125-144. https://doi.org/10.1123/jtpe.26.2.125

Hoy, A. W., \& Spero, R. B. (2005). Changes in teacher efficacy during the early years of teaching: A comparison of four measures. Teaching and Teacher Education, 21(4), 343-356. https://doi.org/10.1016/j.tate.2005.01.007

Hudson, T. J. (2009). New teacher job dissatisfaction and attrition from 1983-2005: A meta-analysis (Thèse de doctorat inédite). Accessible par ProQuest Dissertations \& Theses. (3383204).

Hung, C.-H. (2012). Internal marketing, teacher job satisfaction, and effectiveness of central Taiwan primary schools. Social Behavior and Personality, 40(9), 1435-1450. https://doi.org/10.2224/sbp.2012.40.9.1435

Jeffrey, D., \& Sun, F. (2008). Persévérance et santé chez les enseignants en insertion professionnelle. In L. Portelance, J. Mukamurera, S. Martineau \& C. Gervais (Eds.), L'insertion dans le milieu scolaire: une phase cruciale du développement professionnel de l'enseignant (pp. 163-183). Québec, QC: Presses de l'Université Laval.

Johnson, S. M., \& Birkeland, S. E. (2003). Pursuing "sense of success": New teachers explain their career decisions. American Educational Research Journal, 40(3), 581-617. https://doi.org/10.3102/00028312040003581

Karacan-Doğan, P. K., Akyel, Y., \& Doğan, I. (2018). Examination of the relationship between job satisfaction and job stress of physical education teachers. Acta Didactica Napocensia, 11(1), 1-11. https://doi.org/10.24193/adn.11.1.1

Karsenti, T., Collin, S., \& Dumouchel, G. (2013). Le décrochage enseignant: état des connaissances. International Review of Education, 59(5), 549-568. https://doi.org/10.1007/s11159-013-9367-z

Leroux, M., Beaudoin, C., Grenier, J., Turcotte, S., \& Rivard, M.-C. (2016). Similarities and differences in risk and protective factors in teacher induction for prospective elementary and physical and health education teachers. Journal McGill, 5l(2), 807-832. https://doi.org/10.7202/1038604ar

Mäkelä, K., \& Hirvensalo, M. (2015). Work ability of Finnish physical education teachers. The Physical Educator, 72, 384-398. https://doi.org/10.18666/TPE-2015-V72-I5-6186

Mäkelä, K., \& Whipp, P. R. (2015). Career intentions of Australian physical education teachers. Journal of Teaching in Physical Education, 21, 504-520. https://doi.org/10.1177/1356336X15584088

Marquis, A. (2017). Étude de la dynamique motivationnelle d'enseignants en éducation physique et à la santé au primaire en période d'insertion professionnelle (Mémoire de maîtrise inédit). Université de Sherbrooke, Canada.

Martineau, S., Gervais, C., Portelance, L., \& Mukamurera, J. (2008). L'insertion professionnelle des enseignants: une problématique complexe qui requiert un regard multiple. In L. Portelance, J. Mukamurera, S. Martineau \& C. Gervais (Eds.), L'insertion dans le milieu scolaire: une phase cruciale du développement professionnel de l'enseignant (pp. 1-8). Québec, QC: Presses de l'Université Laval.

McCluney, E. N., Fallaize, A., \& Schempp, P. (2018). How today's mentoring relationships can influence tomorrow's physical education. Journal of Physical Education, Recreation \& Dance, 89(3), 34-37. https://doi.org/10.1080/07303084.2017.1417928 
Morris, D. B., Usher, E. L., \& Chen, J. A. (2017). Reconceptualizing the sources of teaching self-efficacy: A critical review of emerging literature. Educational Psychology Review, 29, 795-833. https://doi.org/10.1007/s10648-016-9378-y

Mukamurera, J. (2018). Les préoccupations, le sentiment de compétence et les besoins de soutien professionnel des enseignants débutants: un état de la situation au Québec. In J. Mukamurera, J.-F. Desbiens \& T. Perez-Roux (pp. 189-237), Se développer comme professionnel dans les professions adressées à autrui. Conditions, modalités et perspectives. Éditions JFD.

Mukamurera, J., Bourque, J., \& Ntebuste, J. G. (2010). La situation d'insertion professionnelle chez les enseignants du primaire au Québec. Vivre le Primaire, 23(2), 36-37.

Mukamurera, J., \& Fontaine, S. (2017). Les premières années d'enseignement: réalité professionnelle, besoins de soutien et mesures d'insertion offertes dans les commissions scolaires au Québec. In B. Kutsyuruba \& K. Walker (Eds.), The bliss and blisters of early career teaching: A pan-Canadian perspective (pp. 181-203). Burlington: Word \& Deed Publishing.

Nascimento, R. K., Folle, A., Rosa, A. I., \& Both, J. (2016). Job satisfaction among physical education teachers from the municipal network of São José-Sc. Journal of Physical Education, 27(1), 2-11. https://doi.org/10.4025/jphyseduc.v27i1.2740

Organisation de coopération et de développement économiques (OCDE). (2005). Le rôle crucial des enseignants. Attirer, former et retenir des enseignants de qualité. Paris, France: OCDE.

Organisation de coopération et de développement économiques (OCDE). (2014). Résultats de TALIS 2013: Une perspective internationale sur l'enseignement et l'apprentissage. Paris, France: OCDE. Retrieved from https://www.oecd-ilibrary.org/education/resultats-de-talis-2013_9789264214293-fr\#

Parker, M., Patton, K., \& Tannehill, D. (2012). Mapping the landscape of communities of practice as professional development in Irish physical education. Irish Educational Studies, 31, 311-327. https://doi.org/10.1080/03323315.2012.710067

Perry, N. E., Brenner, C., Collie, R. J., \& Hofer, G. (2015). Thriving on challenge: Examining one teacher's view on sources of support for motivation and well-Being. Exceptionality Education International, 25, 6-34.

Pillen, B., Beijaard, D., \& Den, P. B. (2013). Tensions in beginning teachers' professional identity development, accompanying feelings and coping strategies. European Journal of Teacher Education, 36(3), 240-260. https://doi.org/10.1080/02619768.2012.696192

Portelance, L., Mukamurera, J., Martineau, S., \& Gervais, C. (2008). La réussite de l'insertion professionnelle des enseignants: une responsabilité individuelle et collective. In L. Portelance, J. Mukamurera, S. Martineau \& C. Gervais (Eds.), L'insertion dans le milieu scolaire: une phase cruciale du développement professionnel de l'enseignant (pp. 267-276). Québec, QC: Presses de l'Université Laval.

Richards, K. A. R. (2015). Role socialization theory: The sociopolitical realities of teaching physical education. European Physical Education Review, 21, 379-393. https://doi.org/10.1177/1356336X15574367

Roulston, K. (2014). Analysing interviwes. In U. Flick (Ed), The SAGE handbook of qualitative data analysis (pp. 297-312). London: Sage Publications. https://doi.org/10.4135/9781446282243.n20

Schwandt, T. A., \& Gates, E. F. (2018). Case study methodology. In N. K. Denzin \& Y. S. Lincoln (Eds.), The SAGE Handbook of Qualitative Research (5th ed., pp. 341-358). London, UK: SAGE Publications Ltd.

Sharplin, E., O'Neill, M., \& Chapman, A. (2011). Coping strategies for adaptation to new teacher appointments: Intervention. Teaching and Teacher Education, 27(1), 136-146. https://doi.org/10.1016/j.tate.2010.07.010

Skaalvik, E. M., \& Skaalvik, S. (2011). Teacher job satisfaction and motivation to leave the teaching profession: Relations with school context, feeling of belonging, and emotional exhaustion. Teaching and Teacher Education, 27(6), 1029-1038. https://doi.org/10.1016/j.tate.2011.04.001

Stroot, S. A. (2003). Organizational socialization: Factors impacting beginning teachers. In S. Silverman \& C. Ennis (Eds), Student learning in physical education: Applaying research to enhance instruction (pp. 339-366). Champaign: Human Kinetics.

Stroot, S. A., \& Ko, B. (2006). Induction of beginning physical educators into the school setting. In D. Kirk, M. O'Sullivan \& D. Macdonald (Eds.), Handbook of Research in Physical Education (pp. 425-448). London, UK: Sage Publications Ltd. https://doi.org/10.4135/9781848608009.n24 
Tait, M. (2008). Resilience as a contributor to novice teacher success, commitment, and retention. Teacher Education Quarterly, 35(4), 57-75.

Théorêt, M., \& Leroux, M. (2014). Comment améliorer le bien-être et la santé des enseignants? Des ressources pour la résilience éducationnelle. Louvain-la-Neuve, Belgique: De Boeck Supérieur.

Ünlü, H., \& Filiz, B. (2019). Work ability of the Turkish physical education teachers. Research Quarterly for Exercise and Sport, 90, 666-677. https://doi.org/10.1080/02701367.2019.1642995

Van den Berghe, L., Cardon, G., Aelterman, N., Tallir, I. B., Vansteenkiste, M., \& Haerens, L. (2013). Emotional exhaustion and motivation in physical education teachers: A variable-centered and person-centered approach. Journal of Teaching in Physical Education, 32(3), 305-320. https://doi.org/10.1123/jtpe.32.3.305

Van Maele, D., \& Van Houtte, M. (2012). The role of teacher and faculty trust in forming teachers' job satisfaction: Do years of experience make a difference? Teaching and Teacher Education, 28, 879-889. https://doi.org/10.1016/j.tate.2012.04.001

Weiss, H. M. (2002). Deconstructing job satisfaction: Separating evaluations, beliefs and affective experiences. Human Resource Management Review, 12(2), 173-194. https://doi.org/10.1016/S1053-4822(02)00045-1

Whipp, P. R., \& Salin, K. (2018). Physical education teachers in Australia: Why do they stay? Social Psychology of Education, 21, 897-914. https://doi.org/10.1007/s11218-018-9443-0

Yin, R. K. (2014). Case study research: Design and methods (5th ed.). Thousand Oaks, CA: Sage Publications Ltd.

\section{Copyrights}

Copyright for this article is retained by the author, with first publication rights granted to the journal.

This is an open-access article distributed under the terms and conditions of the Creative Commons Attribution license (http://creativecommons.org/licenses/by/4.0/). 